\title{
Sodium Alginate/Ultrasonic-Assisted Biodegradation of Oestrogens in Soil
}

\author{
Ying Chen ${ }^{1,2}$, Chen Zhang ${ }^{3}$, Yaling Zeng ${ }^{1,2}$, Yu Li ${ }^{1,2 *}$ \\ 'Resource and Environment Institute of North China Electric Power University, Beijing 102206, China \\ ${ }^{2}$ The State Key Laboratory of Regional Optimization of Energy Systems, \\ North China Electric Power University, Beijing 102206, China \\ ${ }^{3}$ State Environmental Protection Key Laboratory for Lake Pollution Control, \\ Chinese Research Academy of Environmental Sciences, Beijing 100012, China
}

Received: 30 January 2015

Accepted: 22 March 2015

\begin{abstract}
The aim of this study was to assess the effect of sodium alginate-immobilized bacteria and ultrasonic assistance on the biodegradation of oestrogens in soil. The studied oestrogens were oestrone (E1), oestradiol (E2), oestriol (E3), 17 $\alpha$-ethinylestradiol (EE2), and bisphenol-A (BPA). A central composite design was developed to determine the optimal conditions of the three variables (ultrasound time, sodium alginate concentration, and amount of sodium alginate beads) for the removal of oestrogens. Moreover, the experiment utilized a quantitative structure-biodegradation relationship (QSBR) to analyze the effect of the estrogenic physicochemical properties on the enhancement of the biological degradation mechanism. The results indicated that the optimal conditions are an ultrasound time of three min, a sodium alginate concentration of $3 \%$, and $4 \mathrm{~g}$ of sodium alginate beads. These conditions resulted in removal rates of $100 \%, 100 \%, 93 \%, 96.47$, and $51.87 \%$ for E1, E2, EE2, BPA, and E3, respectively, after seven days. These rates were 1.7, 1.4, 1.3, 1.2, and 2.1 times the microbial degradation rate of the suspended state, respectively. Based on a Pearson correlation analysis, the oestrogen molecule polar surface area (PSA) and hydrophobicity (represented by logKow) were significantly related to the effect of biodegradation. An analysis of the OSBR model (with the oestrogen biodegradation rates as a dependent variable and PSA and logKow as independent variables) indicated the following: PSA negatively correlated and logKow positively correlated with oestrogen removal, and these effects were synergistic. Therefore, sodium alginate/ultrasound assistance can significantly improve the biodegradation rates of oestrogens in soil, while simultaneously adjusting other environmental conditions would influence and control the biodegradation processes of oestrogens.
\end{abstract}

Keywords: oestrogen, sodium alginate, ultrasonic-assistant, biodegradation, QSBR

\section{Introduction}

Endocrine-disrupting chemicals (EDCs) are naturally occurring or man-made compounds present in the environment that can bind to oestrogen receptors [1] and interfere

*e-mail: liyuxx8@hotmail.com with normal endocrine effects in animals and humans at $\mathrm{ng} \cdot \mathrm{L}^{-1}$ levels [2]. Oestrone (E1), oestradiol (E2), and oestriol (E3) are naturally occurring oestrogens that can cause serious reproductive and developmental disorders and interfere with endocrine regulation in the whole body, the nervous system, and immune system, and lead to cancer [3]. 
$17 \alpha$-ethinylestradiol (EE2) and bisphenol A (BPA) are man-made oestrogens. EE2 is the main ingredient in aquaculture feed, oral contraceptives, and hormone supplements that cause feminization [4] in several species of fish [5], molluscs [6], amphibians [7], birds [8], and mammals [9] at concentrations as low as $0.1 \mathrm{ng} \cdot \mathrm{L}^{-1}$ [2]. BPA can lead to malignant tumours, and these effects are compounded in combination with cadmium and ultraviolet light $[10$, $11]$.

As a frequently detected environmental pollutant, oestrogens are not only found in water but also in soil. To date, most oestrogen degradation studies have mainly focused on the estrogenic transformation and control in water $[12,13]$. EDCs can be removed by the action of wastewater treatment plants (WWTPs) [14, 15], including the nitrification of activated sludge [4] and removal by aerobic and anaerobic treatment processes in a membrane bioreactor [16]. Oestrogens can undergo several fates after entering soil, including microbial immobilisation and mineralisation, abiotic transformation, sorption to the solid phase, uptake by plants, leaching, and runoff [17]. Several researchers have studied estrogenic sorption courses in soil $[18,19]$. However, sorption is a pollutant transfer process, and only some oestrogens pass through this process; biodegradation allows for the complete removal of the contaminant. Hence, Liu Jianlin [20] attempted to use Pseudomonas putida for the biodegradation of oestrogens, but the degradation effects were not obvious. Therefore, this study aimed to control and remove EDCs in soil.

Sodium Alginate (SA) is famous for its cost effectiveness, relatively low cytotoxicity, exceptional immobilisation and mass transfer performance, and high enrichment in microbial cells. Simultaneously sodium alginate is widely used as a gelling agent due to its ability to form gels under mild conditions with divalent cations such as calcium, and is useful as a carrier of microorganisms [21, 22]. Therefore, it has become one of the most widely used embedding media. Moreover, ultrasound has emerged as an alternative source of homogenizing energy with potential applications in enzymatic reaction control. Ultrasound energy acts by increasing the interaction between phases in a system by cavitation caused by the collapse of bubbles, whereas the ultrasonic jet disrupts the boundary phase and causes emulsification. When applied in aqueous solutions or suspensions, ultrasound increases mixing, shearing, and mass transfer rate of the system, reducing process time when compared with other conventional mixing techniques. In biotechnological processes, ultrasound has been applied for some enzymatic reactions, wastewater treatment, and biofuel production, with very good results [23]. The aim of this study was to assess the effects of sodium alginate-immobilised bacteria and ultrasound assistance on the biodegradation of oestrogens in soil, to determine the optimal conditions for this process and to provide a theoretical foundation and basis for oestrogen removal.
Table 1 . The factors and levels of central composite design for estrogenic biodegradation in soil.

\begin{tabular}{|c|c|c|c|c|c|}
\hline Factor & -1.682 & -1 & 0 & +1 & +1.682 \\
\hline Ultrasound time (min) & 1.32 & 2 & 3 & 4 & 4.68 \\
\hline $\begin{array}{c}\text { Sodium alginate } \\
\text { concentration (\%, w/v) }\end{array}$ & 1.32 & 2 & 3 & 4 & 4.68 \\
\hline $\begin{array}{c}\text { Amount of sodium } \\
\text { alginate beads (g) }\end{array}$ & 2.32 & 3 & 4 & 5 & 5.68 \\
\hline
\end{tabular}

\section{Materials and Methods}

\section{Chemicals and Instruments}

E1 ( $\geq 97 \%)$, E2 ( $\geq 97 \%)$, EE2 ( $\geq 97 \%)$, E3 ( $\geq 99 \%)$, and BPA $(\geq 98.3 \%)$ were purchased from Sigma-Aldrich (Steinheim, Germany). Sodium alginate was of analytical grade and obtained from J\&K Chemical (Beijing, China). The biodegradation metabolites were analysed with highperformance liquid chromatography (HPLC, Agilent, 1200) coupled with a numerical control ultrasonic cleaner (KQ100) from Kun Shan Ultrasonic Instruments Co. Ltd., China.

\section{Methods \\ Preparation of Sodium Alginate Beads}

The Pseudomonas putida cells were grown in enrichment medium for $24 \mathrm{~h}$ and mixed with a sodium alginate solution. To immobilise Pseudomonas putida, a mixture of sodium alginate and seed culture was dropped into a $2 \%$ (w/v) $\mathrm{CaCl}_{2}$ solution using syringes. Subsequently, the sodium alginate beads were stored after immobilisation in a refrigerator at $4^{\circ} \mathrm{C}$ for $12 \mathrm{~h}$, washing with normal saline and draining on sterile filter paper.

\section{Experimental Design and Optimization of Estrogenic Biodegradation}

A certain amount of oestrogens was added to a mineral medium and mixed with different amounts of sodium alginate beads according to central composite design schedule. The samples were then oscillated (avoid light) in the incubator after ultrasonic assistance.

To determine the optimal conditions of the three variables (ultrasound time, sodium alginate concentration, and amount of sodium alginate beads) for the removal of oestrogens, a central composite design was developed and a response surface method was used (the above three variables served as influencing factors, and the biodegradation rates of oestrogens served as response values). The coding of each influence factor, high and low level of specific values is shown in Table 1.

According to the central composite design factors level table, a schedule for enhancing biodegradation rates of oestrogens was obtained and is demonstrated in Table 2. 
Table 2. The central composite design for estrogenic biodegradation in soil.

\begin{tabular}{|c|c|c|c|}
\hline No. & $\begin{array}{c}\text { Ultrasound time } \\
(\mathrm{min})\end{array}$ & $\begin{array}{c}\text { Sodium alginate } \\
\text { concentration } \\
(\%, \mathrm{w} / \mathrm{v})\end{array}$ & $\begin{array}{c}\text { Amount of } \\
\text { sodium alginate } \\
\text { beads }(\mathrm{g})\end{array}$ \\
\hline 1 & 2 & 2 & 3 \\
\hline 2 & 2 & 2 & 5 \\
\hline 3 & 2 & 4 & 3 \\
\hline 4 & 2 & 2 & 3 \\
\hline 5 & 4 & 2 & 5 \\
\hline 6 & 4 & 4 & 5 \\
\hline 7 & 4 & 3 & 4 \\
\hline 8 & 4 & 3 & 4 \\
\hline 9 & 1.32 & 3 & 4 \\
\hline 10 & 4.68 & 3 & 4 \\
\hline 11 & 3 & 3 & 4 \\
\hline 12 & 3 & 3 & 4 \\
\hline 13 & 3 & 3 & 5.68 \\
\hline 14 & 3 & 3 & 4 \\
\hline 15 & 3 & 3 & 4 \\
\hline 16 & 3 & 3 & 4 \\
\hline 17 & 3 & 3 & 4 \\
\hline 18 & 3 & 3 & 4 \\
\hline 19 & 3 & 3 & 4 \\
\hline 20 & 3 & 3 & 4 \\
\hline
\end{tabular}

\section{Results and Discussion}

\section{Optimisation of Oestrogenic Biodegradation Based on Response Surface Method}

Statistical Analysis System (SAS) software was used to construct a response surface figure of the enhancing biodegradation rates of oestrogens (Fig. 1).

As shown in Fig. 1, the biodegradation rates of E1 and E3 negatively correlated with the ultrasonic time and were minimised after three min, at which point they increased again; the rates of EE2 and BPA increased with the treatment time, and the biodegradation rate of E2 slightly decreased. E1 is one of the intermediate products of the degradation of $\mathrm{E} 2$ and $\mathrm{EE} 2$; $\mathrm{E} 3$ not only is one of the intermediate degradation products of E1, E2, and EE2, but also is the ultimate metabolic product. Appropriate intensity ultrasound accelerated growth and improved the ability of microorganisms to absorb and degrade oestrogens. With the addition of appropriate intensity ultrasound, the degradation rates of other oestrogen compounds increased, producing $\mathrm{E} 1$ and $\mathrm{E} 3$, that is increasing the amounts of E1 and E3 at the same time, so their degradation rates decreased.
The degradation rate of E1 positively correlated with the sodium alginate concentration, while that of $\mathrm{E} 2$ was relatively constant; the degradation rates of EE2 and E3 at first tended to negatively correlate with the sodium alginate concentration and were minimised at 3\%; the degradation rate of BPA first increased and then decreased and was maximised at a sodium alginate concentration of $3 \%$. Although sodium alginate frees fixed microorganisms in a limited amount of space, which significantly improves the microbial concentration per unit volume in the reaction system with the optimal dosage of sodium alginate; above this dosage, sodium alginate's balling with microorganisms will be relatively difficult, meaning the ability of immobilized microorganisms also decreased, so the degradation rate of BPA first increased and then decreased.

The degradation rate of $\mathrm{E} 3$ was also decreased with the addition of sodium alginate. E3 not only is one of the intermediate degradation products of other oestrogen compounds, but also is the ultimate metabolic product. With the addition of sodium alginate, the degradation rates of other oestrogen compounds increased with more E3 produced, increasing the amounts of E3 in the system so that the degradation rate of $\mathrm{E} 3$ decreased with the addition of sodium alginate.

The biodegradation rate of E1 slightly decreased as the amount of immobilised Pseudomonas putida cells increased, and was minimised at a cell load of $5.68 \mathrm{~g}$; the degradation rate of $\mathrm{E} 2$ at first tended to increase as the cell load decreased and was maximised at a load of $4 \mathrm{~g}$; the degradation rates of EE2 and E3 decreased and were minimised at a cell load of $4 \mathrm{~g}$; the degradation rate of BPA first increased and then exhibited a change in trend, reaching a maximum value at $3 \%$.

Comparing all experimental conditions, the biodegradation ratios of the five oestrogens were simultaneously maximised at an ultrasound treatment time of $3 \mathrm{~min}$, sodium alginate concentration of $3 \%$, and sodium alginate beads load of $4 \mathrm{~g}$. At optimum conditions, the biodegradation ratios of E1 and E2 were 100\% after 3d; and those of EE2, E3, and BPA were $93 \%, 51.87 \%$, and $96.47 \%$ after $7 d$, respectively.

\section{The Rule of Enhancing Biodegradation under Optimum Conditions}

Fig. 2 shows the biodegradation behaviour of E1, E2, $\mathrm{EE} 2$, and E3, and BPA for 7d at optimum conditions.

As shown in Fig. 2, the biodegradation ratio of E1 reached $100 \%$ after $1 \mathrm{~d}$, the ratio suddenly decreased due to partial E2 oxidation into E1 [13] on 3d, and then increased to $100 \%$ again; over time, the BPA, EE2, and E3 ratios continued to increase after $7 \mathrm{~d}$ and reached $96.47 \%, 93 \%$, and $51.87 \%$, respectively; the EE2 ratio was $100 \%$ after $2 \mathrm{~d}$ at optimum conditions. Therefore, E1, E2, EE2, and BPA reached biodegradation ratios above $90 \%$ after $7 \mathrm{~d}$, while that of E3 was lower than $60 \%$ at optimum conditions.

At optimum conditions, the removal rates of E1, E2, EE2, BPA, and E3 reached $100 \%, 100 \%, 93 \%, 96.47$, and $51.87 \%$ after $7 \mathrm{~d}$, respectively, and were $1.7,1.4,1.3,1.2$, 

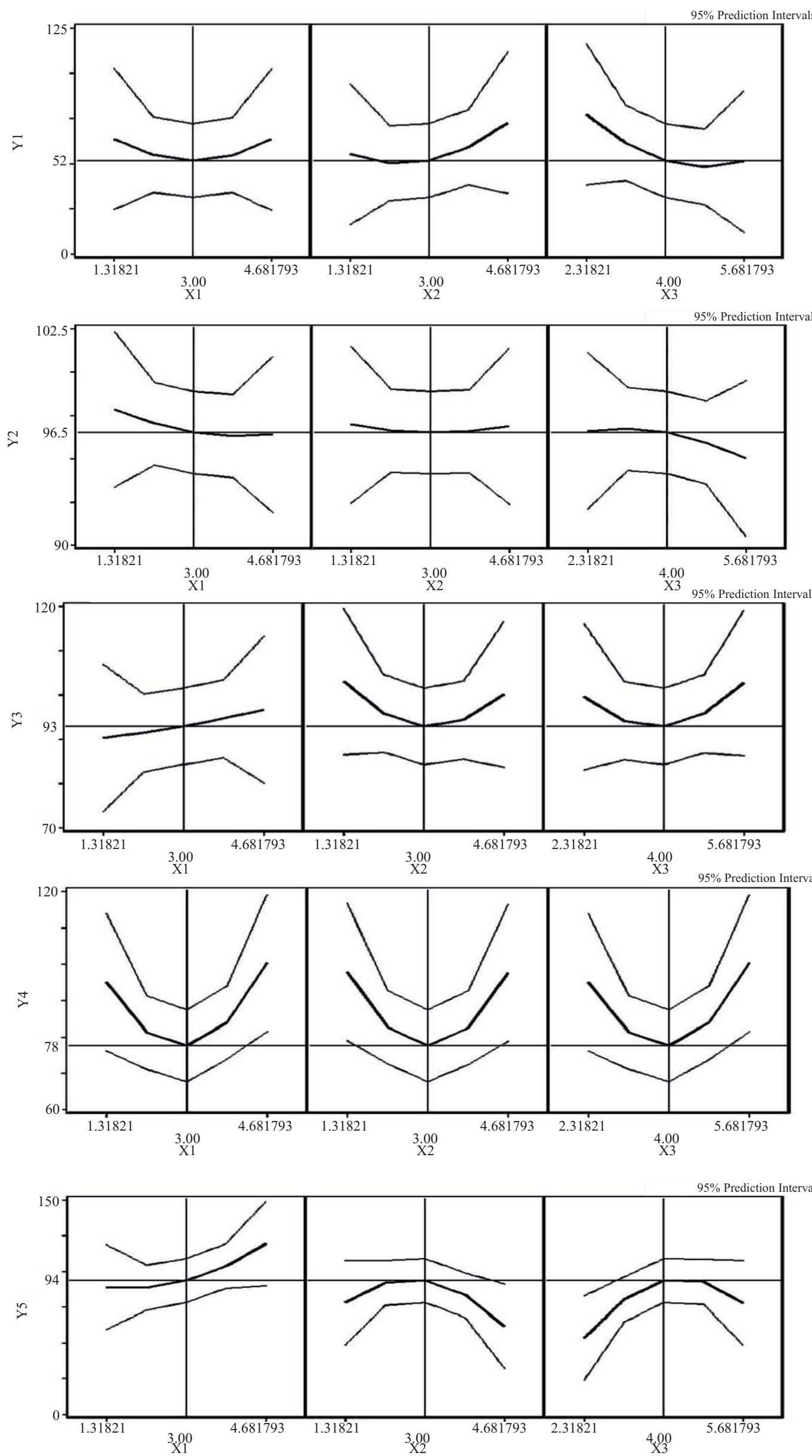

Fig. 1. The effect of factors on the biodegradation of EDCs (Y1-Y5 are the degradation rates of E1, E2, EE2, E3, and BPA, respectively). 


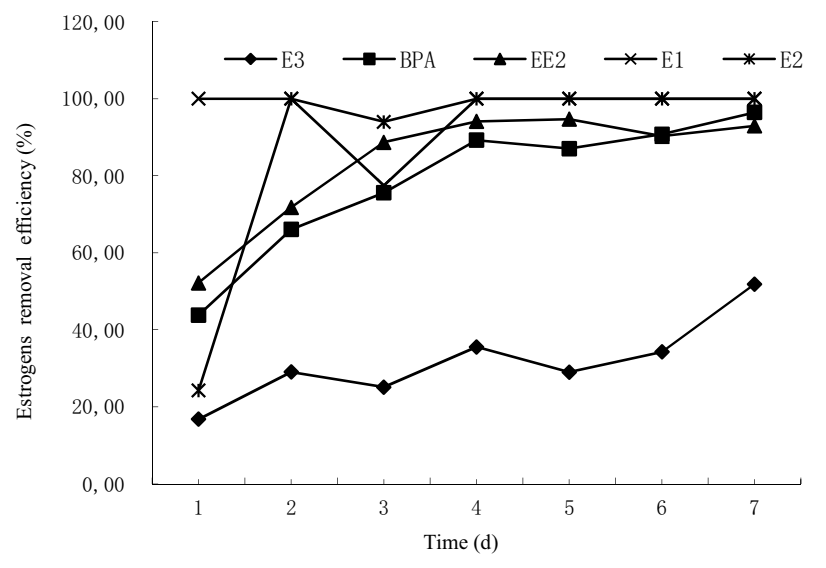

Fig. 2. The oestrogens biodegradation behaviour at optimum conditions.

and 2.1 times that of the suspended state [20]. By improving microbial stability to enhance the degradation of oestrogens, sodium alginate frees fixed microorganisms, such as Pseudomonas putida, in a limited amount of space, which significantly improves the microbial concentration per unit volume in the reaction system [24]. Furthermore, the application of immobilized microorganisms not only helps maintain high bacterial cell concentrations, but also increases the biological activity of the microorganisms, makes control separation easy, and protects cells against toxic substances and changes in environment factors [25, 26]. Microorganisms are attached to the carrier in the form of colonies, and the microbial fixation of sodium alginate improves their stabilities and benefits their growth. In addition, immobilization that allows achievement of an active and stable enzyme, with good specificity by the substrate, generally eliminates most of the disadvantages of the use of enzymes [27].

The immobilisation of intact enzymes on solid supports is important to help strengthen and prolong the biodegradation ability of microorganisms [28]. It was reported that lowintensity ultrasound improved microbial metabolism and stimulated physiological activities [29]. In addition, appropriate intensity ultrasound can increase the permeability of cell membrane, amplify the cells inside and outside the transportation of material, and improve the efficiency of microbial cell metabolism to promote enzyme activity, accelerate growth, and improve the ability of microorganisms to absorb and degrade organic matter [23, 30].
The maximum degradation rate of E3 reached only $51.87 \%$ but showed the largest variation, mainly because E3 is one of the intermediate products of the degradation of other oestrogen compounds; E2 is a primary metabolite that can produce E3 by hydration [31]; EE2 and E1 are secondary metabolites, and E3 is the ultimate metabolic product. The oestrogen activity of these compounds ranks as follows: E2 > EE2 > E1 > E3 [32]. This observation agrees with the literature, which suggests that E3 is the intermediate degradation product of other oestrogen compounds [19]. The specific processes of oestrogens are shown in Table 3.

\section{Analysis of the Biodegradation Mechanism of Oestrogens}

\section{The Selection of Estrogenic Properties on Biodegradation Ratios}

As shown in Table 4, the Matlab software was used to conduct a preliminary analysis and select the physicochemical properties of oestrogens, which demonstrated an apparent correlation between the estrogenic properties and the removal of estrogenic contaminants.

As shown in Table 4, the hydrophobicity (logKow) of oestrogen $(\mathrm{P}=0.05 \leq 0.05)$ was significantly related to the biodegradation ratios, and the polar surface area (PSA) $(\mathrm{P}=$ $0.002<0.01)$ significantly correlated with this hydrophobicity. Therefore, the occurrence and types of PSA and logKow appear to be important factors that govern the removal efficiency of oestrogens.

\section{Analysis of Estrogenic Biodegradation Mechanism Based on QSBR Model}

A QSBR model was built to study the correlation between the estrogenic properties and the removal of estrogenic contaminants. In this model, the properties served as independent variables and the biodegradation served as the dependent variable.

The QSBR model can be expressed as follows:

$$
\begin{gathered}
Y=-95.48 * X_{1}+1242.34 * X_{2}+4.61 X_{1}^{*} X_{2} \\
+0.84 X_{1} * X_{1}-196.23 X_{2} * X_{2} \\
\left(\mathrm{R}^{2}=0.9897, \mathrm{n}=10, \mathrm{~F}=71.8542, \mathrm{P}=0.0026\right)
\end{gathered}
$$

...where $X_{1}$ is PSA, $X_{2}$ is $\operatorname{logKow}$, and $Y$ represents the biodegradation ratios. The PSA represents the total surface

Table 3. Transformation of select EDCs.

\begin{tabular}{|c|c|c|c|}
\hline Compound & Precursor & Intermediate product & Ultimate product \\
\hline BPA & polycarbonate, epoxy resin & - & 4-isopropenyl or BPA trimer, tetramer \\
\hline E1 & conjugated oestrogens, E2 [31], EE2 [33] & E3 [31] & 2-hydroxy E1, 16 $\alpha$-hydroxy E1 etc. \\
\hline E2 & oestradiol valerate, oestradiol cypionate & E1, E3 [31] & 2-hydroxy E2, testosterone analogues etc. [31, 34] \\
\hline EE2 & mestranol & E1 [31] & C2-6 molecule binary carboxylic acid [31] \\
\hline E3 & nylestriol, nilestriol etc. & - & 4-methoxy E3 etc. \\
\hline
\end{tabular}


Table 4. Pearson correlation analysis of the correlation between estrogenic properties.

\begin{tabular}{|c|c|c|c|c|c|c|c|c|}
\hline Properties & $\begin{array}{l}\text { Heat of } \\
\text { Formation }\end{array}$ & $\begin{array}{l}\text { Gibbs } \\
\text { Energy }\end{array}$ & $\begin{array}{l}\text { Ideal gas } \\
\text { thermal } \\
\text { capacity }\end{array}$ & $\begin{array}{l}\text { Formal } \\
\text { Charge }\end{array}$ & $\begin{array}{c}\text { Connolly } \\
\text { Accessible } \\
\text { Area }\end{array}$ & $\begin{array}{c}\text { Connolly } \\
\text { Molecular } \\
\text { Area }\end{array}$ & $\begin{array}{l}\text { Connolly Solvent } \\
\text { Excluded Volume }\end{array}$ & $\begin{array}{l}\text { Exact } \\
\text { Mass }\end{array}$ \\
\hline Pearson correlation & 0.662 & 0.574 & -0.286 & - & -0.257 & -0.247 & -0.209 & -0.303 \\
\hline Significant & 0.224 & 0.312 & 0.640 & - & 0.676 & 0.688 & 0.736 & 0.620 \\
\hline $\mathrm{N}$ & 5 & 5 & 5 & 5 & 5 & 5 & 5 & 5 \\
\hline Properties & Mass & Mol Weight & Ovality & $\begin{array}{l}\text { Principal } \\
\text { Moment }\end{array}$ & $\begin{array}{c}\text { Mol } \\
\text { Refractivity }\end{array}$ & $\begin{array}{l}\text { Partition } \\
\text { Coefficient }\end{array}$ & Balaban Index & $\begin{array}{l}\text { Cluster } \\
\text { Count }\end{array}$ \\
\hline Pearson correlation & -0.303 & -0.30 & -0.31 & -0.23 & -0.14 & 0.69 & -0.28 & -.244 \\
\hline Significant & 0.621 & 0.62 & 0.62 & 0.70 & 0.82 & 0.20 & 0.65 & .693 \\
\hline $\mathrm{N}$ & 5 & 5 & 5 & 5 & 5 & 5 & 5 & 5 \\
\hline Properties & $\begin{array}{l}\text { Molecular } \\
\text { Topological } \\
\text { Index }\end{array}$ & $\begin{array}{l}\text { Num } \\
\text { Rotatable } \\
\text { Bonds }\end{array}$ & $\begin{array}{c}\text { Polar } \\
\text { Surface } \\
\text { Area }\end{array}$ & Radius & $\begin{array}{c}\text { Shape } \\
\text { Attribute }\end{array}$ & $\begin{array}{c}\text { Shape } \\
\text { Coefficient }\end{array}$ & Sum of Degrees & $\begin{array}{l}\text { Sum of } \\
\text { Valence } \\
\text { Degrees }\end{array}$ \\
\hline Pearson correlation & -0.174 & 0.197 & $-0.987 *$ & 0.158 & -0.244 & -0.158 & -0.208 & -0.411 \\
\hline Significant & 0.779 & 0.751 & 0.002 & 0.800 & 0.692 & 0.800 & 0.737 & 0.492 \\
\hline $\mathrm{N}$ & 5 & 5 & 5 & 5 & 5 & 5 & 5 & 5 \\
\hline Properties & $\begin{array}{c}\text { Topological } \\
\text { Diameter }\end{array}$ & $\begin{array}{c}\text { Total } \\
\text { Connectivity }\end{array}$ & $\begin{array}{l}\text { Total Valence } \\
\text { Connectivity }\end{array}$ & $\begin{array}{l}\text { Wiener } \\
\text { Index }\end{array}$ & $\operatorname{logKoc}$ & $\operatorname{logKow}$ & Polarisability & $\begin{array}{l}\text { Surface } \\
\text { tension }\end{array}$ \\
\hline Pearson correlation & 0.158 & 0.134 & 0.318 & -0.258 & 0.661 & 0.878 & -0.293 & -0.866 \\
\hline Significant & 0.800 & 0.830 & 0.602 & 0.675 & 0.225 & 0.050 & 0.632 & 0.058 \\
\hline $\mathrm{N}$ & 5 & 5 & 5 & 5 & 5 & 5 & 5 & 5 \\
\hline
\end{tabular}

Bold: the result of a preliminary analysis about the physicochemical properties of oestrogens, which demonstrated an apparent correlation between the estrogenic properties and the removal of estrogenic contaminants.

* The coefficient statistically significant $(\mathrm{P})$ located between 0.01 and 0.05 .

area of polar molecules, including oxygen, nitrogen, and the hydrogen bonds; logKow is described as a physical property, i.e., that oestrogen molecules repel each other in water. $X_{1}^{*} X_{1}$ represents its own second-order interaction effect on the biodegradation rate in the system; $X_{2}^{*} X_{2}$ represents its own second order interaction effect on the biodegradation rate in the system; $X_{1}^{*} X_{2}$ represents their interaction effects on the biodegradation rate in the system. The $\mathrm{R}^{2}$ of the model was calculated to be 0.9897 , which indicates that the model is robust.

As shown in Eq. (1), the PSA negatively correlated and the $\log$ Kow positively correlated with oestrogen removal, and these effects were synergistic. Compared with the main effect of PSA $\left(X_{1}\right)$, the PSA $\left(X_{1}\right)$ was negatively correlated with the biodegradation rate $(Y)$, and its own second order interaction effect $\left(X_{1}^{*} X_{1}\right)$ was a positive value, recognized as synergistic effect to the biodegradation rate $(Y)$, although this effect is not significant. In the same way, $\operatorname{logKow}\left(X_{2}\right)$ was positively correlated with oestrogen removal, and its own second order interaction effect $\left(X_{2}{ }^{*} X_{2}\right)$ was not only significant, but also recognized as an antagonism to the biodegradation rate $(Y)$. Because the coefficient $X_{1} * X_{2}$ is a second-order interaction effect of both $X_{1}$ and $X_{2}$, being a positive value, the joint effect of PSA and logKow on the biodegradation rate $(Y)$ was recognized as a synergistic effect.

The existing research showed that the value of logKow directly corresponds to the hydrophobicity of oestrogen compounds. The surface hydrophobicity of microbial cells is an important property that directly affects the efficiency of various bioprocesses, such as bioremediation, waste treatment, and green biotechnologies, using whole microbial cells [35]. Compounds with higher logKow values can improve the efficiency of microbial degradation, which would enhance its adhesion to microbial cells, modulated by the type of growth substrate, growth phase, and the presence of biosurfactants/chemical surfactants, and promote the growth and reproduction of microorganisms and production of microflora [36-38]. The PSA negatively correlated with the penetrability of cells, which was detrimental to the growth and reproduction of microorganisms. A larger PSA indicates more hydrogen bonds and hydrophilic groups, which negatively impacts microbial degradation efficiency $[39,40]$.

\section{Conclusions}

Sodium alginate/ultrasound-assistance could significantly improve the biodegradation rates of oestrogens in soil, 
while oestrogenic PSA and logKow were significantly related to the biodegradation rates. Moreover, the PSA negatively and the logKow positively correlated with oestrogen removal, and these effects were synergistic. This study has provided a theoretical foundation showing that adjusting the environmental conditions would appropriately influence and control the biodegradation processes of oestrogens.

\section{Acknowledgements}

The authors are grateful for the financial support provided by the Ministry of Science and Technology of China ('973' Project No. 2004CB3418501).

\section{References}

1. GIOIOSA L., FISSORE E., GHIRARDELLI G., PARMIGIANI S., PALANZA P. Developmental exposure to lowdose estrogenic endocrine disruptors alters sex differences in exploration and emotional responses in mice. Horm Behav. 52, (3), 307, 2007.

2. PURDOM C. E., HARDIMAN P. A., BYE V. V. J., ENO N. C., TYLER C. R., SUMPTER J. P. Estrogenic effects of effluents from sewage treatment works. Chem and Ecol. 8, (4), 275, 1994

3. CHANG H. S., CHOO K. H., LEE B., CHOI S.J. The methods of identification, analysis and removal of endocrine disrupting compounds (EDCs) in water. J Hazard Mater. 172, (1), $1,2009$.

4. CLOUZOT L., DOUMENQ P., ROCHE N., MARROTA B. Kinetic parameters for $17 \alpha$-ethinylestradiol removal by nitrifying activated sludge developed in a membrane bioreactor. Bioresource Technol. 101, (16), 6425, 2010.

5. LESLEY J. M., CLINTON C. Review of evidence: Are endocrine-disrupting chemicals in the aquatic environment impacting fish populations? Sci. Total Environ. 343, (1-3), 1, 2005.

6. KETATA I., DENIER X., HAMZA CHAFFAI A., MINIER C. Endocrine-related reproductive effects in mollusks. Comp Biochem Physiol C Toxicol Pharmacol. 147, (3), 261, 2008.

7. GYLLENHAMMAR I., HOLM L., EKLUND R., BERG C. Reproductive toxicity in Xenopus tropicality after developmental exposure to environmental concentrations of ethynylestradiol. Aquat Toxicol. 91, (2), 171, 2009.

8. BRUNSTRÖM B., AXELSSON J., MATTSSON A., HALLDIN K. Effects of estrogens on sex differentiation in Japanese quail and chicken. Gen Comp Endocrinol. 163, (12), 97, 2009

9. LATENDRESSE J. R., BUCCI T. J., OLSON G., MELLICK P., WEIS C. C., THORN B., NEWBOLD R. R., DELCLOS K. B. Genistein and ethinyl estradiol dietary exposure in multigenerational and chronic studies induce similar proliferative lesions in mammary gland of male SpragueDawley rats. Reprod Toxicol. 28, (3), 342, 2009.

10. KOPONEN P.S., KUKKONEN J. V. K. Effects of bisphenol A and artificial UVB radiation on the early development of Rana temporaria. J. Toxicol. Environ. Health. 65, (13), 947, 2002.

11. SOGAWA N., ONODERA K., SOGAWA C.A., MUKUBO Y., FUKOKA H., ODA N., FURUTA H. Bisphenol A enhances cadmium toxicity through estrogen receptor. Methods Find Exp Clin Pharmacol. 23, (7), 6621, 2001.
12. SARKAR S., ALI S., REHMANN L., NAKHLA G., MADHUMITA B. R. Degradation of estrone in water and wastewater by various advanced oxidation processes. J. Hazard. Mater., 278, (C), 16, 2014.

13. SHI J.H., CHEN Q.C., LIU X.W., ZHAN X.M., LI J., LI Z.B. Sludge/water partition and biochemical transformation of estrone and 17ß-estradiol in a pilot-scale step-feed anoxic/oxic wastewater treatment system. Biochem. Eng. J, 74, 107, 2013.

14. GONZALEZ S., PETROVIC M., BARCELO D. Removal of a broad range of surfactants from municipal wastewater-comparison between membrane bioreactor and conventional activated sludge treatment. Chemosphere. 67, (2), 335, 2007.

15. CLARA M., STRENN B., GANS O., MARTINEZ E., KREUZINGER N. AND KROISS H. Removal of selected pharmaceuticals, fragrances and endocrine disrupting compounds in a membrane bioreactor and conventional wastewater treatment plants. Water Res. 39, (19), 4797, 2005.

16. ABARGUESA M.R., FERRERB J., BOUZASA A., SECO A. Removal and fate of endocrine disruptor chemicals under lab-scale postreatment stage. Removal assessment using light, oxygen and microalgae. Bioresource Technol. 149, (C), 142, 2013.

17. LUCAS S. D., JONES D. L. Biodegradation of estrone and $17 \beta$-estradiol in grassland soils amended with animal wastes. Soil Biol. Biochem. 38, (9), 2803, 2006.

18. SUN K., RO K., GUO M.X., NOVAK J., MASHAYEKHI H., XING B.S. Sorption of bisphenol A, 17 $\alpha$-ethinyl estradiol and phenanthrene on thermally and hydrothermally produced biochars. Bioresource Technol. 102, (10), 5757, 2011.

19. VaN EMMERIK T., ANGOVE M. J., JOHNSON B. B., WELLS J. D., FERNANDES M. B. Sorption of 17ß-estradiol onto selected soil minerals. J Colloid Interface Sci. 266, (1), 33, 2003.

20. LIU J.L., Ph. D. thesis. Study on the adsorption behaviors and biodegradation of estrogen chemicals in soil system. North China electric power university, 2012 [In Chinese].

21. FU S., THACKER A., SPERGER D. M., BONI R. L., BUCKNER I. S., VELANKAR S., MUNSON E. J., BLOCK L. H. Relevance of Rheological Properties of Sodium Alginate in Solution to Calcium Alginate Gel Properties. AAPS. Pharm. Sci. Tech., 12, (2), 453, 2011.

22. KAKITA H., KAMISHIMA H. Some properties of alginate gels derived from algal sodium alginate. J. Appl. Phycol., 20, (5), 93, 2008.

23. PALUDO N., ALVES J.S., ALTMANN C., AYUB M.A., FERNANDEZ-LAFUENTE R., RODRIGUES R.C. The combined use of ultrasound and molecular sieves improves the synthesis of ethyl butyrate catalyzed by immobilized Thermomyces lanuginosus lipase. Ultrason. Sonochem., 22, 89, 2015.

24. JEONG J. J., KIM J. H., KIM C., HWANG I., LEE K. 3and 4-alkylphenol degradation pathway in Pseudomonas sp. strain KL28: genetic organization of the lap gene cluster and substrate specificities of phenol hydroxylase and catechol 2 , 3-dioxygenase. Microbiol. 149, (11), 3265, 2003.

25. ZAIN N.A.M., SUHAIMI M.S., IDRIS A. Hydrolysis of liquid pineapple waste by invertase immobilized in PVAalginate matrix. Biochem. Eng. J., 50, (3), 83, 2010.

26. CHEN C.Y., CHEN S.C., FINGAS M., KAO C.M. Biodegradation of propionitrile by Klebsiella oxytoca immobilized in alginate and cellulose triacetate gel. J. Hazard. Mater., 177, (1/2/3), 856, 2010.

27. RICHETTI A., MUNARETTO C.B., LERIN L.A., BATISTELLA L., VLADIMIR OLIVEIRA J., DALLAGO R.M., ASTOLFI V., LUCCIO M.D., MAZUTTI M.A., DE 
OLIVEIRA D., TREICHEL H. Immobilization of inulinase from Kluyveromyces marxianus NRRLY-7571 using modified sodium alginate beads. Bioproc. Biosyst. Eng., 35, (3), 383, 2012.

28. WIESEL I., WUBKER S. M., REHM H. J. Degradation of polycyclic aromatic hydrocarbons by an immobilized mixed bacterial culture. Appl. Microbiol. Biotechnol., 39, (1), 110, 1993.

29. GAO S.P., GILLIAN D. L., ASHOKKUMAR M., YACINE HEMAR Y. Inactivation of microorganisms by low-frequency high-power ultrasound: 1. Effect of growth phase and capsule properties of the bacteria. Ultrason. Sonochem., 21, (1), 446, 2014.

30. CHISTI Y. Sonobioreactors: using ultrasound for enhanced microbial productivity. Trends. Biotechnol., 21, (2), 89, 2003.

31. LAI K., SCRIMSHAW M., LESTER J. Biotransformation and bioconcentration of steroid estrogens by Chlorella vulgaris [J]. Appl. Environ. Microb., 68, (2), 859, 2002.

32. PUMA G.L., PUDDU V., TSANG H.K., GORA A., TOEPFER B. Photocatalytic oxidation of multicomponent mixtures of estrogens (estrone (E1), 17 $\beta$-estradiol (E2), 17 $\alpha$ ethynylestradiol (EE2) and estriol (E3)) under UVA and UVC radiation: Photon absorption, quantum yields and rate constants independent of photon absorption. Appl. Catal. BEnviron., 99, 388, 2010.

33. REN H.Y., JI S.L., AHMAD N., WANG D., CUI C.W. Degradation characteristics and metabolic pathway of $17 \alpha-$ ethynylestradiol by Sphingobacterium sp. JCR5. Chemosphere, 66, (2), 340, 2007.

34. BILA D., MONTALVAO A.F., AZEVEDO D.A., DEZOTTI M. Estrogenic activity removal of $17 \beta$-estradiol by ozonation and identification of by-products. Chemosphere, 69, (5), 736, 2007.

35. HORI K., HIRAMATSU N., NANNBU M., KANIE K., OKOCHI M., HONDA H., WATANABE H. Drastic change in cell surface hydrophobicity of a new bacterial strain, Pseudomonas sp. TIS1-127, induced by growth temperature and its effects on the toluene-conversion rate. J. Bio. SCI. Bioeng., 107, (3), 250, 2009.

36. CHANG W.N., LIU C.W., LIU H.S. Hydrophobic cell surface and bioflocculation behavior of Rhodococcus erythropolis. Process. Biochem., 44, (9), 955, 2009.

37. OBUEKWE C. O., AL-JADI Z. K., AL-SALEH E. S. Hydrocarbon degradation in relation to cell-surface hydrophobicity among bacterial hydrocarbon degraders from petroleum-contaminated Kuwait desert environment. Int. Biodeter. Biodegr., 63, (3), 273, 2009.

38. CHAKRABORTY S., MUKHERJI S., MUKHERJI S. Surface hydrophobicity of petroleum hydrocarbon degrading Burkholderia strains and their interactions with NAPLs and surfaces. Colloid. Surface. B., 78, (1), 101, 2010.

39. TRONDE A., NORDEN B., JEPPSSON A.B., BRUNMARK P., NILSSON E., LENNERNAS H., BENGTSSON U.H. Drug absorption from the isolated perfused rat lung: correlations with drug physicochemical properties and epithelial permeability. J. Drug. Target., 11, (1), 61, 2003.

40. MAGHRABY G.M.M., WILLIAMS A.C., BARRY B.W. Drug interaction and location in liposomes: correlation with polar surface areas. Int. J. Pharmaceut., 292,(1-2), 179, 2005. 